\title{
How Biojodis and Cyanobacteria Alleviate the Negative Influence of Predicted Environmental Constraints on Growth and Physiological Activity of Corn Plants
}

\author{
Krzysztof Piotrowski ${ }^{1}$, Zdzislawa Romanowska-Duda ${ }^{1 *}$, \\ Mieczyslaw Grzesik ${ }^{2}$ \\ ${ }^{1}$ Department of Ecophysiology and Plant Development, University of Lodz, \\ Banacha 12/16, 90-131 Lodz, Poland \\ ${ }^{2}$ Research Institute of Horticulture, \\ Konstytucji 3 Maja 1/3, 96-100 Skierniewice, Poland
}

Received: 2 October 2015

Accepted: 4 December 2015

\begin{abstract}
Information concerning corn plant development within predicted environmental constraints and the possibility of alleviating their negative influence by ecological compounds is limited. Thus the aim of our research was to evaluate the physiological activity, growth, and development of corn plants under the expected climate-change conditions and treated with Biojodis (certificated extract of humus and active iodine; Jodavita, Lithuania) and Cyanobacteria (a mixture of monocultures of Microcystis aeruginosa MKR 0105 and Anabaena sp. PCC 7120). 'Cyrkon' corn plants (Zea mays L.) were cultivated in several simulated predicted climate conditions, including constant or periodically changing temperature and soil moisture content. During the vegetative season they were treated at three-week intervals using Biojodis at concentrations of 1.0, 2.0, or 3.0\%, and Cyanobacteria, and then assessed using growth and physiological parameters.

The obtained results showed the corn's different reactions to the applied conditions. Plants that grew at constant or periodically changing different temperatures $\left(0\right.$ to $\left.40^{\circ} \mathrm{C}\right)$ or in unsatisfactorily $(20 \%$ m.c. $)$ or excessively ( $60 \%$ m.c.) watered soils, developed slowly in comparison with those growing at $20^{\circ} \mathrm{C}$ and in optimally moistened media ( $30 \%$ m.c.). Watering, spraying, or watering and spraying of corn plants with Biojodis (1, 2, 3\%) and a foliar application of Cyanobacteria increased their growth at optimal or unfavourable temperature and in unsatisfactory or excessively moistened soil. The three times spraying with Biojodis (1 or 2\%) and with Cyanobacteria was most promising. The plant development changes related to the used compounds and simulated environmental constraints were associated with the changes in indexes of chlorophyll content in leaves, stability of membranes, gas exchange, and activity of acid or alkaline phosphatase and RNase. The above indicates that foliar and soil application of Biojodis and plant sprayings with Cyanobacteria increased growth of corn cultivated under optimal temperature and soil
\end{abstract}

*e-mail: romano@biol.uni.lodz.pl 
moisture content and partly restored the harmful effects of artificial temperature and water stress on plant development and physiological activity. Biojodis also can increase the iodine content in corn and uptake of nutrients from the soil, and thus decrease environmental pollution.

Keywords: corn, climate changes, Biojodis, Cyanobacteria, physiological activity

\section{Introduction}

Ecological or integrated plant production, with removal or limitation of pesticides, is becoming a top issue among the agriculture and food sector around the world. Most activities related to this production focus on gaining a high yield of plants that are free of toxic components and can be used in the food industry. These demands are becoming more urgent at present due to increased needs for healthy food production, the fast-growing population, and climate changes that may disturb the balance of plant production and ecosystems and lead to future environmental degradation $[1,2]$.

Global climatic changes may cause unpredictable problems connected with yielding, agro technology, plant disease, and pest control, which may lead to a reduction of corn yield and disrupt the food industry due to the importance of this species to human and animal diets. Based on assessing growth in present and simulated conditions, nowadays authors work on ecological methods of plant cultivation relating to the expected temperature changes, soil moisture (artificial drought and rainfall), and application of ecological biostimulators. It is expected that this research will result in increasing food crop yield and plant resistance to stress, as it was observed in the case of other plants [2-11]. It is assumed that biofortification of plants with iodine (a component of Biojodis) can become an alternative method to salt iodization, and that introducing this element to the human diet can affect plant development. Iodine's effect on plant growth has not yet been successfully examined. However, the application of iodine may significantly improve growth in favorable conditions, and thus its application can reduce plant fertilization and environment pollution [12-17].

In recent years, a lot of attention has been paid globally to the use of Cyanobacteria to intensify plant development under favorable conditions. These bluegreen algae have been reported to contain the majority of substations needed for plant growth, among others: amino acids, nutrients, sugar, growth-promoting bioregulators (auxin, GA, cytokinins), vitamins, amino acids, and several other secondary metabolites stimulating plant development [18-24]. Cyanobacteria strains are able to fix atmospheric nitrogen and enrich the soil, rice, wheat, willow, and other plants with this nutrient $[8$, 25-27]. This natural biofertilizer can play an important role in maintenance and buildup of soil fertility, consequently increasing development and yield of plants as discovered in oats, radish, rice, sugarcane, barley, tomato, chili, cotton, wheat, maize, lettuce, gillyflower, grapevine, and willow grown in favorable conditions $[8$, 25-33].
The mentioned findings concerning the positive impact of Biojodis and Cyanobacteria are mostly related to plants grown in favorable conditions and do not apply to plants cultivated under adverse temperature and soil moisture content, particularly in the context of a changing climate. Due to scant information concerning plant growth in the expected climate changing conditions, the aim of the presented research is to evaluate corn development under periodically changing temperatures and soil moisture. We also explored the effects on corn development by the ecological compound Biojodis and Cyanobacteria strains used to alleviate the harmful influence of insufficient temperature and drought or floating.

\section{Material and Methods}

\section{Material and Exposure Regimes}

The commercial grains of corn (Zea mays L.) var. Cyrkon obtained from the Nasiona Kobierzyc breeding company in Poland were sown in 31 pots filled with a mixture of sand and peat $(1: 1=\mathrm{v}: \mathrm{v})$. Then the pots were transferred to the growth chambers with several simulated climate conditions, which probably will take place in the future around the world, including constant or periodically changing temperature and soil moisture content (m.c.).

They were as follows:

1) Constant soil m.c. of $30 \%$ and temperature of 10 , 20 and $40^{\circ} \mathrm{C}$ or temperature subsequently changed, during first month after sowing, in 1 week intervals: $20 / 0 / 20,20 / 40 / 20,20 / 0 / 40 / 20$ and $10 /-5 / 20 / 40 / 20^{\circ} \mathrm{C}$, to simulate the predicted temperature changes during the spring and vegetative seasons; temperatures of 0 and $-5^{\circ} \mathrm{C}$ were used for eight hours only to simulate a slight night frost.

2) Constant temperatures of $20^{\circ} \mathrm{C}$ and $30 \%$ soil m.c. or soil m.c. changed from 20 to $60 \%$ m.c. in threeweek intervals to simulate drought and excessive soil moistening during plant growth.

Plants, after the outflowing of the mentioned periods of changed conditions, were kept at $20^{\circ} \mathrm{C}$ and $30 \%$ soil m.c. up to the end of the vegetative season. During all the vegetative season they were kept under an eight-hours dark/16-hours light cycle (SON-T AGRO $400 \mathrm{~W}, 100$ $\mu \mathrm{molm} \mathrm{s}^{-2} \mathrm{~s}^{-1}$ ). Moisture content of the growing media was regulated by adding the appropriate amount of water or not watering. Water content of growing media was controlled twice daily using a moisture meter (Delta-T Devices Ltd) equipped with WET sensors. The media moisture content was expressed as a percentage of volumetric water content in growing media (\% Vol.) [4]. 
The separate batches of plants grown under these conditions were triple-treated in three-week intervals by watering, spraying, or watering and spraying with Biojodis (containing extract from humus and active iodine; Jodavita, Lithuania) at concentrations of 1.0, 2.0, and 3.0\%, and by foliar application of non-toxic Cyanobacteria (mixture of monocultures of Microcystis aeruginosa MKR 0105 and Anabaena sp. PCC 7120).

The biostimulator Biojodis was obtained from PHU Jeznach Sp.j. Cyanobacteria (a mixture of monocultures of Microcystis aeruginosa MKR 0105 and Anabaena sp. PCC 7120) were cultivated on BG11 medium (ATCC Medium 616 ) at $27^{\circ} \mathrm{C}$ under an $18 \mathrm{~W}$ FAREL lamp according to the procedure outlined by Romanowska-Duda et al. [32]. Prior to application, each monoculture was centrifuged for two min. (4,000 rev/min.) and suspended in water. Then the number of cells was counted using a Fuchs-Rosenthal hemocytometer. Cell density used in

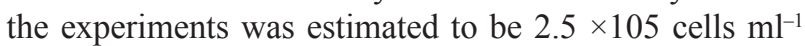
water.

For each treatment three replicates in three series were prepared and every replicate contained 50 plants grown in 50 separate containers. Exposure periods were kept for the entire vegetative season up to flowering.

\section{Determination of Plant Growth and Physiological Activity}

The influence of the mentioned simulated climate conditions and application of biostimulator Biojodis and Cyanobacteria on plant development was evaluated on the basis of measurements of plant height, index of chlorophyll content, activity of net photosynthesis, transpiration, stomatal conductance and concentration of intercellular $\mathrm{CO}_{2}$, activity of acid and alkaline phosphatase, RNase, and electrolyte leakage from leaves. These measurements were performed several times during the vegetative season depending on the intensity of plant growth.

Plant height was measured with ruler from soil to the upper part of leaves [4]. An index of chlorophyll content in leaves was evaluated using Minolta SPAD-502, Japan [34].

Gas exchange (activity of net photosynthesis, stomatal conductance, intercellular concentration of $\mathrm{CO}_{2}$, and transpiration) were measured using the gas analyzer apparatus TPS-2 (PP Systems, USA) [8, 9, 35, 36].

Activities of acid and alkaline phosphatase and RNase in leaves were examined according to methods described by Knypl and Kabzinska [37].

Electrolyte leakage was investigated at $20^{\circ} \mathrm{C}$ after placing 1-g leaf segments in test tubes and adding $3 \mathrm{ml}$ of distilled water. Electrolyte leakage was measured after two and four hours using a CC-551 Elmetron microcomputer conductivity meter [4].

\section{Statistical Analysis}

Results concerning plant height, index of chlorophyll content, gas exchange, activity of acid and alkaline phosphatase and RNase, as well as electrolyte leakage from leaves were analyzed using analysis of variance. The means were separated using Tukey's lowest significant difference (LSD) at an alpha level of 0.05. The data, presented in the graphs also were expressed as average \pm standard deviation (SD).

\section{Results}

\section{Influence of Biojodis and Cyanobacteria on Corn Plant Development at Adverse Temperature and Soil Moisture}

Research showed that the investigated corn plants were very sensitive to the applied temperature and soil moisture content conditions. They developed well at temperatures of $20^{\circ} \mathrm{C}$ and $30 \%$ soil moisture content. Biojodis, applied at concentrations of 1,2 , and $3 \%$ to soil or plants or simultaneously to soil and plants, greatly increased their height and physiological activity at $20^{\circ} \mathrm{C}$ and $30 \%$ soil m.c. Triple application to the plants at concentrations of 1 or $2 \%$ were most effective. Also, a few hours time corn freezing at $-5^{\circ} \mathrm{C}$ severely damaged plants and subsequent treatment with $400 \mathrm{C}$ or Biojodis did not alleviate its negative influence (Figs 1, 3).

A constant temperature of $10^{\circ} \mathrm{C}$ affected poor plant development. Single, double, or triple treatment at this temperature with Biojodis (1.0-3.0\%) had a poor effect on seedling emergence and plant growth (Fig. 3).

A few days' exposure to a constant $40^{\circ} \mathrm{C}$ positively affected corn development, compared to 10 and $20^{\circ} \mathrm{C}$. Biojodis applied to plants increased their growth to a degree similarly as for $20^{\circ} \mathrm{C}$ (Fig. 3). The eight-hours seedling treatment at $0^{\circ} \mathrm{C}$ decreased plant growth and subsequently their exposure to $40^{\circ} \mathrm{C}$ hardly restored the insufficient effect of this chilling. Also, freezing corn at $-5^{\circ} \mathrm{C}$ for a few hours severely damaged plants, which subsequent treatment with $40^{\circ} \mathrm{C}$ or Biojodis did not alleviate (Figs 1, 3).

The obtained results show that growth of corn plants can be determined also by artificial soil moisture content. The decreased plant growth was observed after plant exposure to drought (20\% soil m.c.) or stress caused by excessive soil watering ( $60 \%$ soil m.c.). Plants that grew in the soil periodically dried to $20 \%$ m.c. and then watered up to $60 \%$ m.c. developed slowly in comparison with those growing in media continuously moistened up to $30 \%$ m.c. Treatments with Biojodis at the concentrations and frequencies mentioned above positively affected plant development under stress affected by drought or artificial soil moistening (Fig. 1).

The alterations in plant growth were associated with the respective changes in the index of chlorophyll content in leaves, electrolyte leakage from leaves, and also with the activity of net photosynthesis, stomatal conductance, intercellular concentration of $\mathrm{CO}_{2}$, transportation, and the activity of acid and alkaline phosphatase and RNase (Figs $4,5,6,7,8)$. 

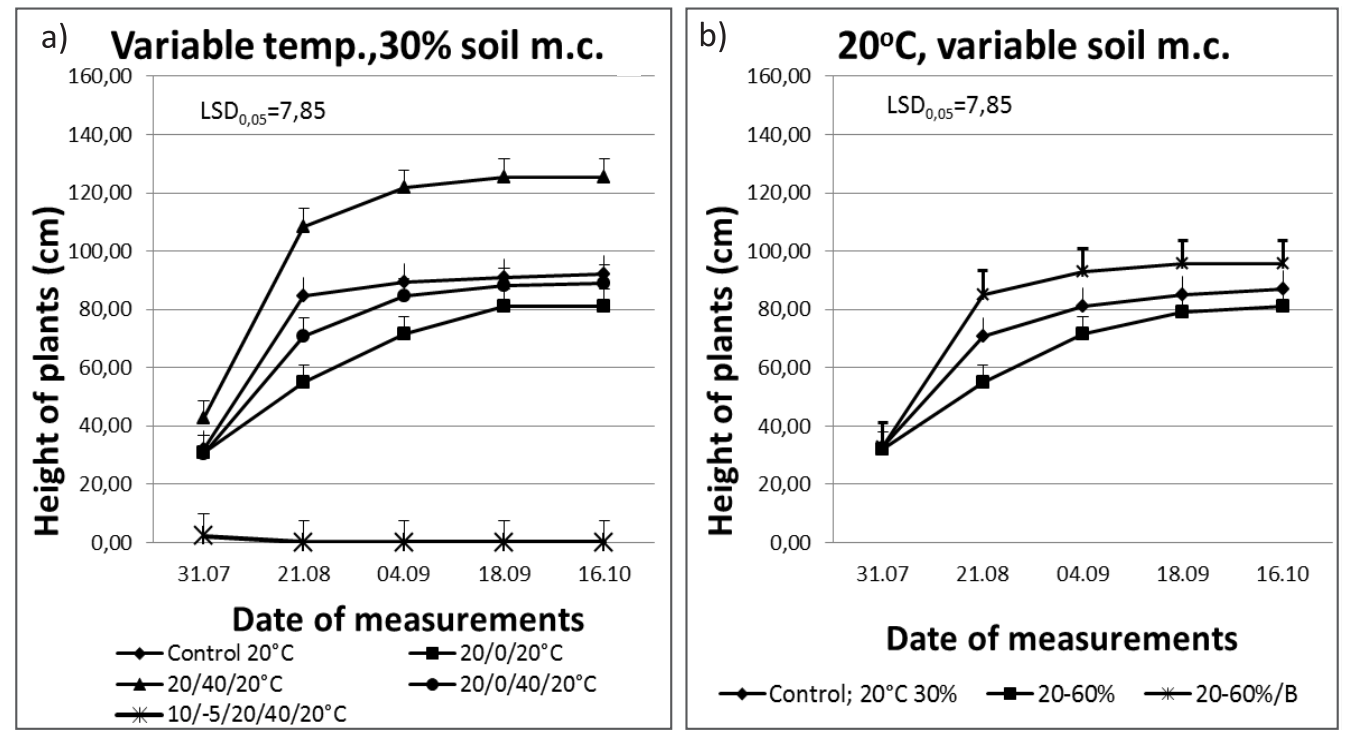

Fig. 1. Height of corn (Zea mays L.) 'Cyrkon' plants grown under the selected, predicted changed-climate conditions: a) constant soil moisture content (m.c.) of $30 \%$ and subsequently changed temperatures during the first month of growth, b) constant $20^{\circ} \mathrm{C}$ and periodically changed soil m.c. from 20 to $60 \%$ and additionally sprayed three times with Biojodis (B).

Vertical bars denote \pm SE. LSD at alpha level of 0.05 .

The performed research shows that foliar application of Cyanobacteria can also increase the development of corn, which is cultivated under adverse conditions of temperature and soil moisture and can partly alleviate the negative influence of this stress on plant growth. The triple foliar biofertilization of corn grown at different temperatures and under adverse moisture content with intact cells of Microcystis aeruginosa MKR 0105 and Anabaena sp. PCC 7120 (Cyanobacteria mixture), resulted in increased height and physiological performance in comparison to control, in which the corn was sprayed with tap water only (Table 1).

\section{Discussion}

The obtained results gives information that corn growth can be negatively affected in the future by several predicted adverse climate changes. The treatments with ecological Biojodis (containing iodine) and non-toxic Cyanobacteria can help to overcome the negative influence of these not-too-drastic but expected climatic conditions on plant growth, minimize pollution of the environment, and increase the suitability of corn as an energy plant and a food enriched with iodine.

The performed research showed different reactions of the corn plants to the applied temperature and soil moisture conditions, as has also been observed in other
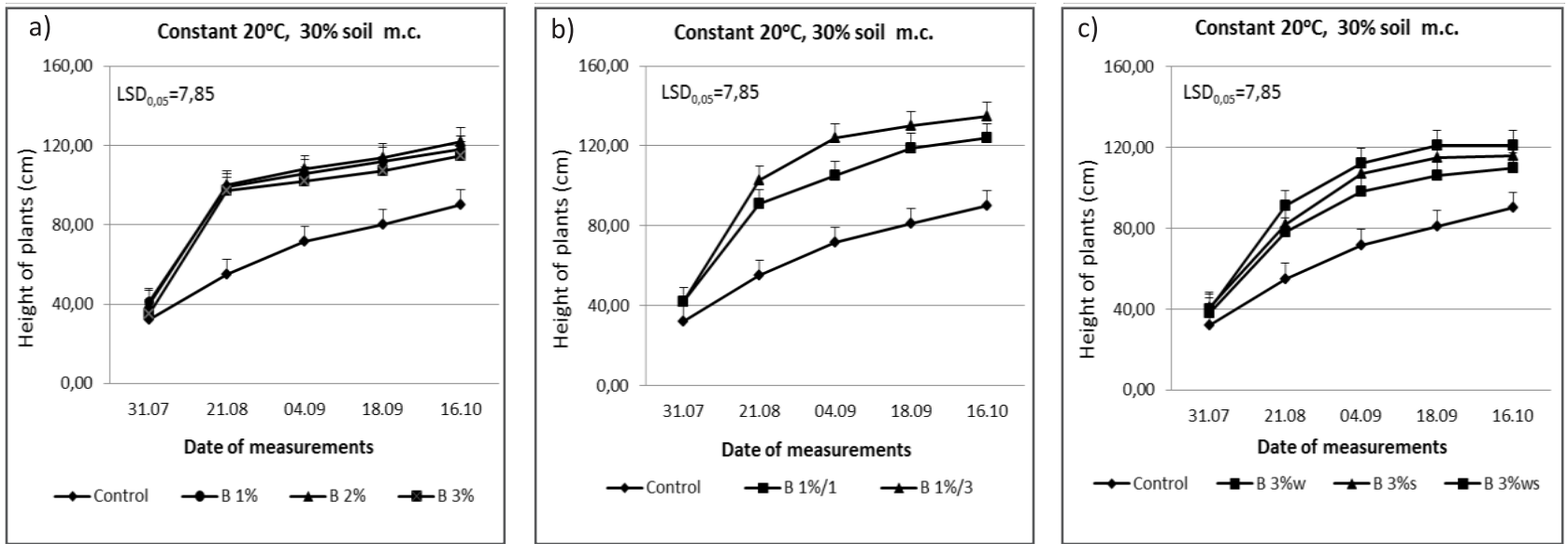

Fig. 2. Height of corn (Zea mays L.) 'Cyrkon' plants grown at constant temperature of $20^{\circ} \mathrm{C}$ and soil moisture content (m.c.) of $30 \%$ and: a) sprayed once with Biojodis at concentrations of $1 \%(\mathrm{~B} 1 \%), 2 \%(\mathrm{~B} 2 \%)$, and $3 \%(\mathrm{~B} 3 \%)$; b) sprayed with Biojodis at concentrations of $1 \%$, one $(\mathrm{B} 1 \% / 1)$ and three times $(\mathrm{B} 1 \% / 3)$ in three-week intervals; $\mathrm{c})$ treated one time with Biojodis at concentrations of $3 \%$ as spraying $(\mathrm{B} 3 \% \mathrm{~s})$, watering $(\mathrm{B} 3 \% \mathrm{w})$, and spraying and watering $(\mathrm{B} 3 \% \mathrm{ws})$. 

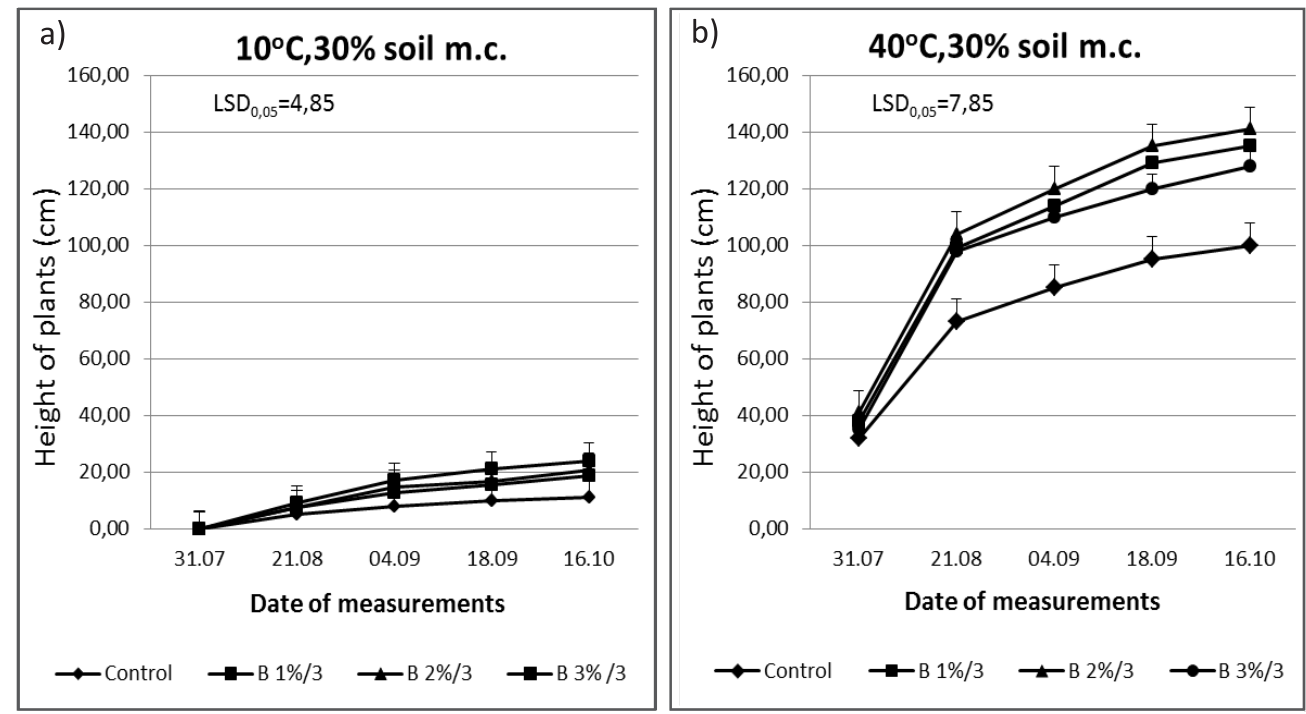

Fig. 3. Height of corn (Zea mays L.) 'Cyrkon' plants grown at constant temperature of $10 ; \mathrm{a})$ or $40^{\circ} \mathrm{C}$; b) and soil moisture content (m.c.) of $30 \%$ and sprayed three times with Biojodis at concentrations of $1 \%(\mathrm{~B} 1 \% / 3), 2 \%(\mathrm{~B} 2 \% / 3)$, and $3 \%(\mathrm{~B} 3 \% / 3)$ at three-week intervals; vertical bars denote \pm SE. LSD at alpha level of 0.05 .

crops $[1,3,5,38]$. All corn plants grew well at $20^{\circ} \mathrm{C}$ and $30 \%$ soil moisture content, which seems to be sufficient conditions for corn development. Transferring these plants to lower temperature and soil moisture decreased their growth dependent of harmfulness of stress, similar to willow and Virginia mallow plants [7, 34].

A temperature of $20^{\circ} \mathrm{C}$, existing now and expected in the future in some regions, is sufficient for corn cultivation because it positively affects grain germination, seedling emergence, and plant growth. Biojodis applied to soil or plants cultivated at $20^{\circ} \mathrm{C}$ and $30 \%$ soil m.c. increases their height and metabolic activity. However, the improvement of this plant development depends on the applied compound concentration and frequency of treatments, as we found also in other experiments investigating other plants.
The most effective was triple plant spraying with Biojodis at concentrations of $1-2 \%$. This is probably connected with the constant presence of this substance in plant tissues. Iodine, the main ingredient of Biojodis, is accumulated in $60 \%$ in the leaves, where it is used directly in biochemical processes. The remaining $40 \%$ of iodine moves together with assimilates in phloem into the stems and roots [16]. The positive effects of Biojodis were obtained also for grapes, Virginia fanpetals, willow, and cabbage $[7,6,11,32,34$,].

The expected spring temperature of $10^{\circ} \mathrm{C}$ in some regions can be harmful for corn cultivation because it affects poor grain germination, seedling emergence, and plant growth. Corn seedling treatments with Biojodis at $10^{\circ} \mathrm{C}$ have inadequate effects in overcoming the negative
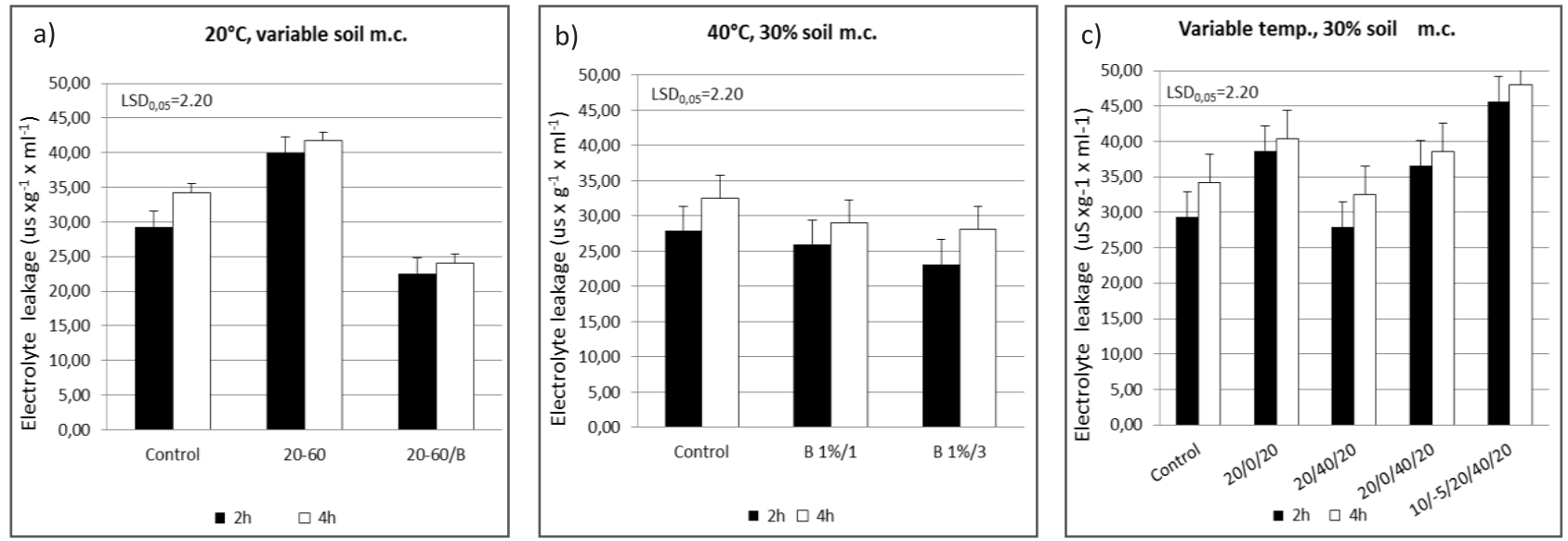

Fig. 4. Electrolyte leakage (after placement in water for two and four hours) from corn (Zea mays L.) 'Cyrkon' plants grown at: a) $20^{\circ} \mathrm{C}$ in periodically changed soil moisture content during plant growth from 20 to $60 \%$ m.c. (20-60) and additionally sprayed with Biojodis $(20-60 / \mathrm{B})$; b) $40^{\circ} \mathrm{C}$ and $30 \%$ soil m.c. and sprayed with Biojodis $(1 \%)$, one $(1 \% / 1)$ and three times $(1$ and $3 \%)$; and c) variable temperatures subsequently changed during the first month and $30 \%$ soil moisture content. Vertical bars denote \pm SE. LSD at alpha level of 0.05 . 

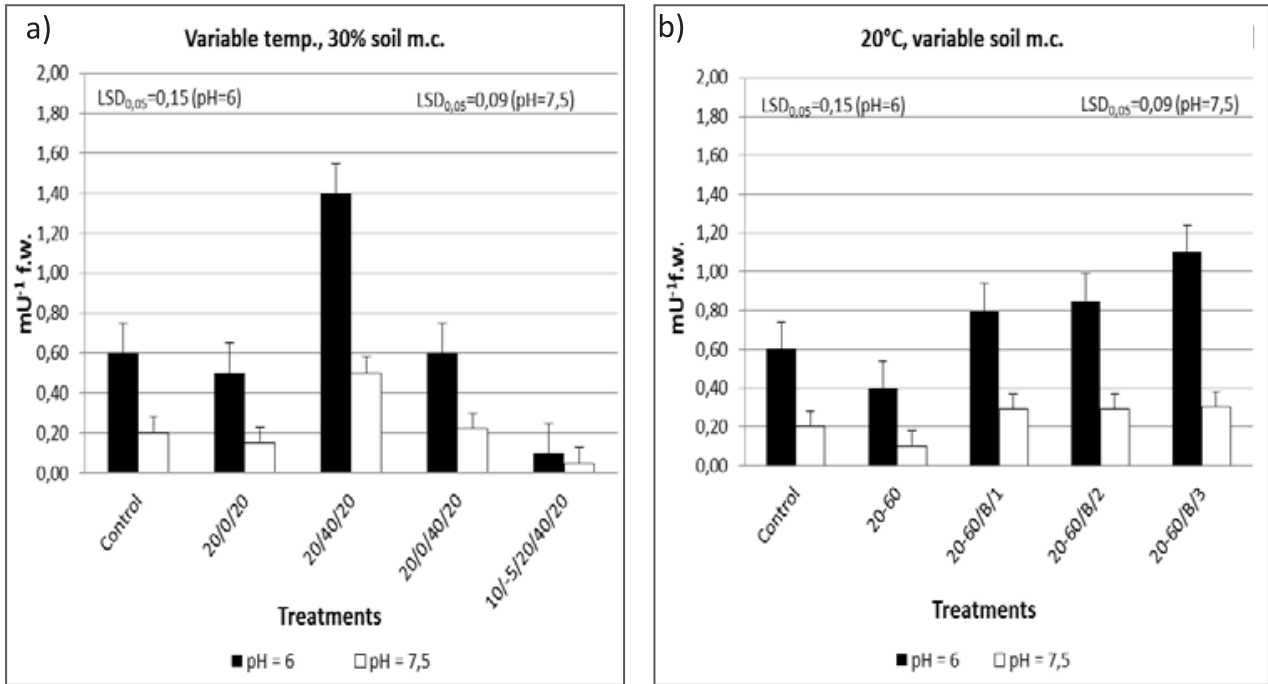

Fig. 5. Activity of acid $(\mathrm{pH}=6)$ and alkaline $(\mathrm{pH}=7.5)$ phosphatase in corn (Zea mays L.) 'Cyrkon' plants grown at: a) variable temperatures subsequently changed during the first month; b) $20^{\circ} \mathrm{C}$ and soil m.c. changed periodically during plant growth from 20 to $60 \%$ m.c., and additionally sprayed with Biojodis $(1 \%)$ one $(B / 1)$, two $(B / 2)$, or three times $(B / 3)$. Vertical bars denote \pm SE. LSD at alpha level of 0.05

influence of this temperature on growth. Similar interdependence was observed in willow and Virginia mallow. This suggests that $10^{\circ} \mathrm{C}$ is too harmful for these plants' growth [7, 34].

The obtained results indicate also that $40^{\circ} \mathrm{C}$, which presumably may periodically determine plant growth in the future, can play a crucial role in the improvement of corn development. Biojodis applied to plants at this temperature increase their growth, as it did at $20^{\circ} \mathrm{C}$. The presented results show also that growth of seedlings, which are currently affected by low temperature $\left(0^{\circ} \mathrm{C}\right)$, is very poor and the subsequent exposure to $40^{\circ} \mathrm{C}$ and Biojodis hardly alleviates the harmful effects of this chilling. Short-time freezing of corn at $-5^{\circ} \mathrm{C}$ damages plants, and subsequent treatment by $40^{\circ} \mathrm{C}$ or Biojodis cannot alleviate its negative influence.
Research also shows that drought or stress caused by excessive soil watering can decrease corn development. Plants growing in unsuitable soils $(20 \%$ m.c., drought; or an excessive $60 \%$ m.c., floating) developed slowly in comparison with those growing in optimally moistened media (30\% m.c.). Treatments with Biojodis restore the harmful effects of these stresses on corn development and metabolic activity. This indicates that the used compound can be applied in the ecological production of healthy food, like corn, which is one of the most important crops in human and animal diet and a raw material for energy production. A similar influence of these compounds was found in China aster and vine grapes, which are also very sensitive to low temperatures during plant development $[4$, $6,10,39]$. The positive effects of Biojodis on plant yield in optimal conditions also was found in strawberry and
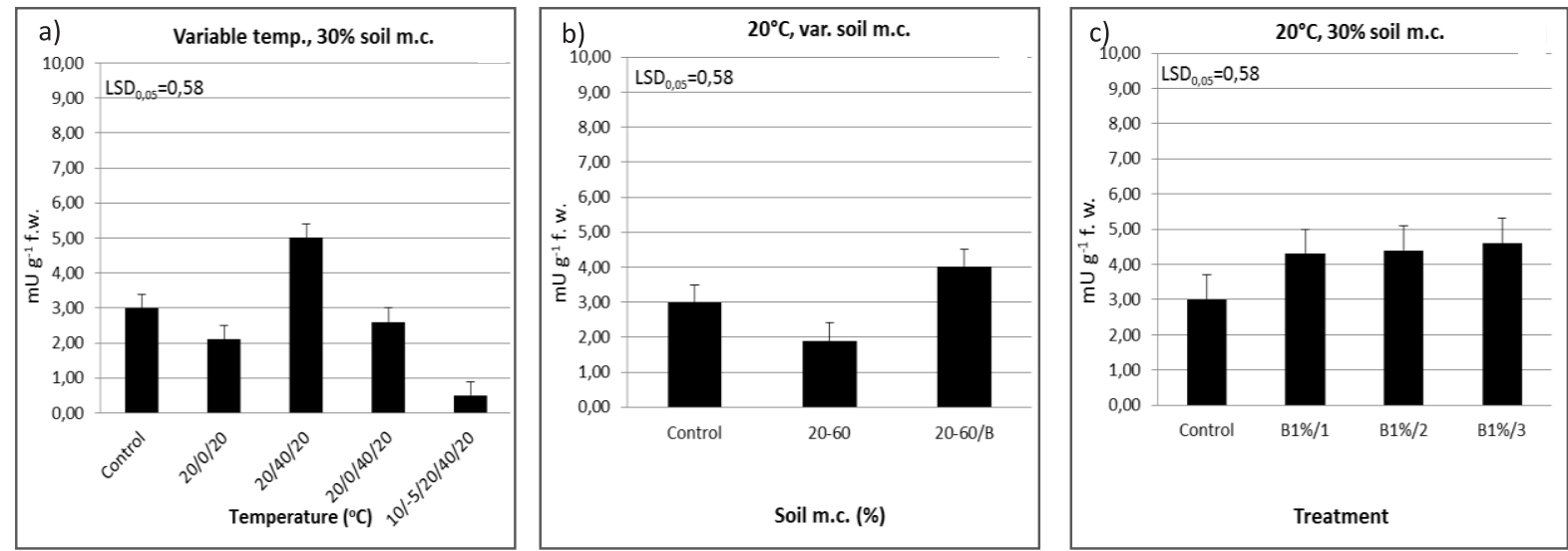

Fig. 6. RNase activity in corn (Zea mays L.) 'Cyrkon' plants grown at: a), subsequently changed temperatures and $30 \%$ soil m.c.; b), $20^{\circ} \mathrm{C}$ and in periodically changed soil m. c. from 20 to $60 \%$ m.c. and additionally sprayed with Biojodis $1 \%$ (B); and c), $20{ }^{\circ} \mathrm{C}$ and $30 \%$ soil m.c. and additionally sprayed with Biojodis (1\%), one (B1\%/1), two (B1\%/2), and three times (B1 and 3\%). Vertical bars denote \pm SE. LSD at alpha level of 0.05 . 

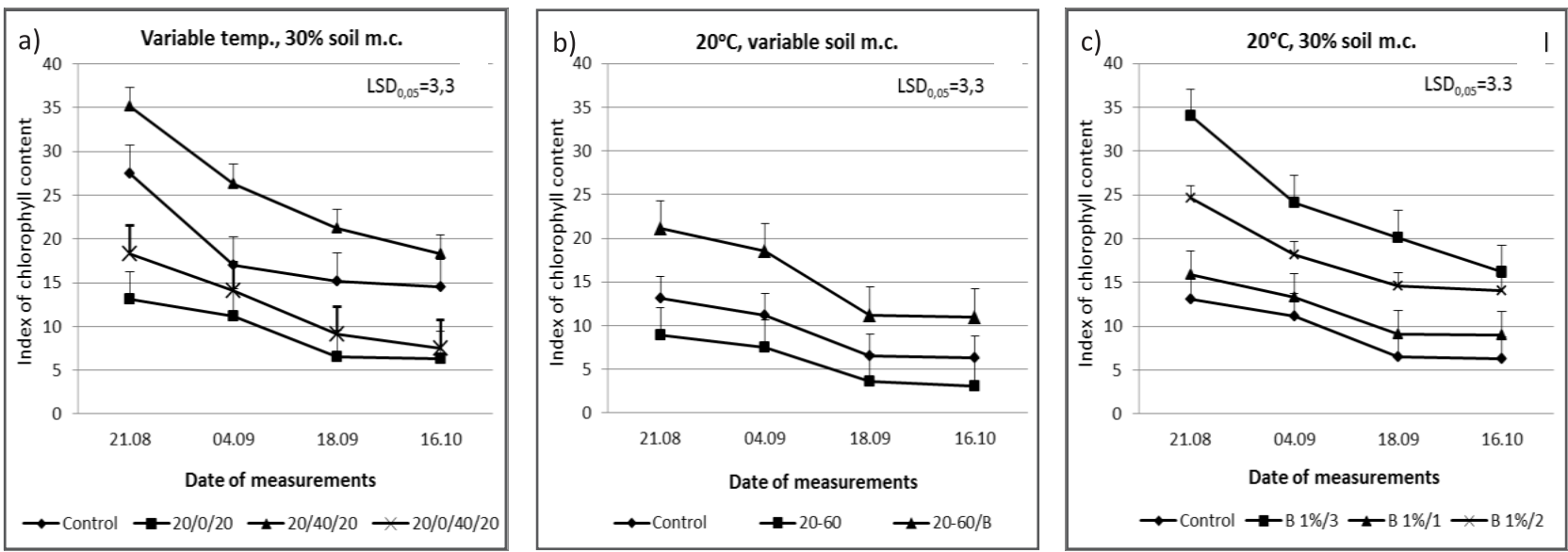

Fig. 7. Index of chlorophyll content (in SPAD units) in corn (Zea mays L.) 'Cyrkon' plants grown at: a) variable temperatures and $30 \%$ soil m.c.; b) $20^{\circ} \mathrm{C}$ and in periodically changed soil m.c. from 20 to $60 \%$ m.c. and additionally sprayed with Biojodis $1 \%$ (B); and c) $20^{\circ} \mathrm{C}$ and $30 \%$ soil m.c. and additionally sprayed with Biojodis $(1 \%)$ one (B1\%/1), two (B1\%/2), and three times (B1\%/3). Vertical bars denote \pm SE. LSD at alpha level of 0.05 .

cucumber $[40,11]$. Biojodis also has increased 'Golden Delicious' apple fruit yield [13].

Plant growth changes relating to the simulated conditions and to the used compound were associated with the similar changes in index of chlorophyll content in leaves, electrolyte leakage from leaves, activity of alkaline and acid phosphatazse, and RNase and gas exchange (activ-
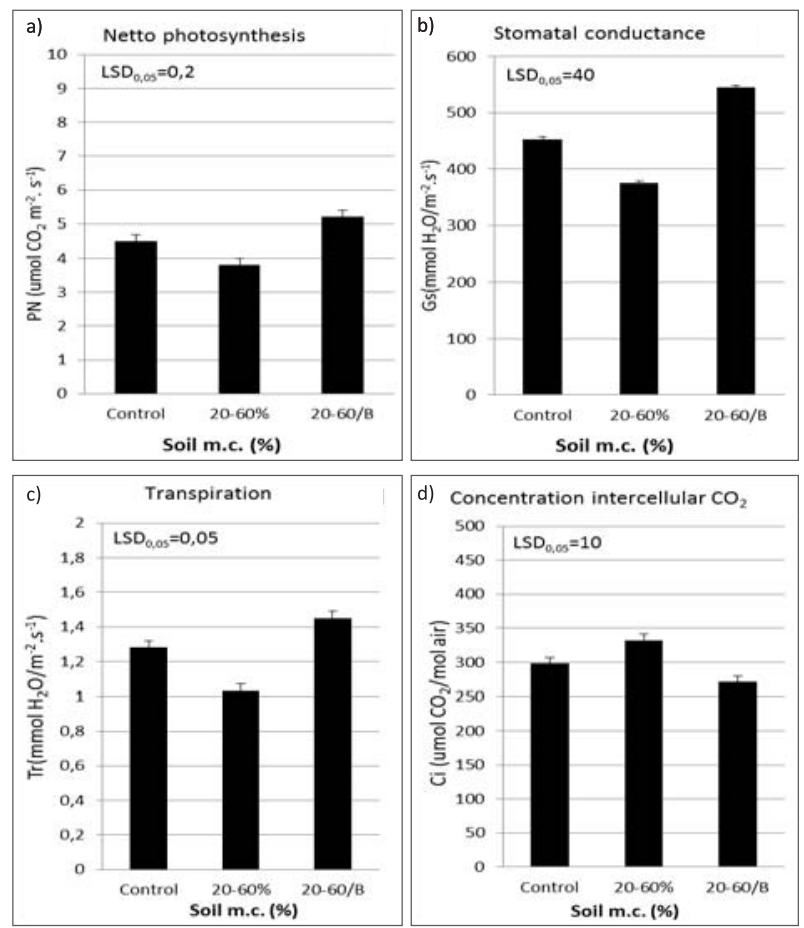

Fig. 8. Net photosynthesis a), stomatal conductance b), transpiration c), and concentration of intercellular $\mathrm{CO}_{2} \mathrm{~d}$ ) in corn (Zea mays L.) 'Cyrkon' plants grown at $20^{\circ} \mathrm{C}$ and in periodically changed soil moisture content during plant growth from 20 to $60 \%$ m.c. and additionally sprayed with Biojodis $1 \%$ (B). Vertical bars denote \pm SE. LSD at alpha level of 0.05 . ity of net photosynthesis, stomatal conductance, intercellular concentration of $\mathrm{CO}_{2}$, and transpiration). This confirms that the increased growth is a consequence of the mentioned physiological processes. The above also indicates that the applied measurement methods are proper markers of the healthy food plant development evaluation $[3,5,41]$.

Biojodis' positive impact may be associated with the beneficial effects of the iodine (important component of this compound) on the cyto-morphological changes in plants. In tomato and cabbage treated with Biojodis, phloem and xylem tissues increased in diameter. In these plants, a well-formed single layer epidermis bordered directly with one layer of collenchymas cells, under which the parenchyma tissue, greater than in control cells, was observed. Increasing the number and diameter of the xylem cells and cell wall thickness were stained more intensely than in controls. After the application of iodine, differentiated morphology of cells and the predominance of the open stomata were also observed. This demonstrates the increased transpiration and gas exchange, after the iodine application necessary for respiration and photosynthesis. Iodine also stimulated the physiological processes in cabbages, causing the cabbage to be less sensitive to climatic stress and adverse growing conditions. Also, in the cabbage treated with Biojodis or iodine we also found an increase of elemens: $\mathrm{K}, \mathrm{P}, \mathrm{Mg}, \mathrm{Ca}, \mathrm{S}, \mathrm{SO}_{4}$ $\mathrm{Fe}, \mathrm{Na}, \mathrm{Mn}, \mathrm{Cu}, \mathrm{Zn}, \mathrm{B}$, and Mo. It can be assumed that all the mentioned metabolic processes - including the higher amount of elements and the greater nutrient transportation from the soil to leaves by the wider xylem cells - could stimulate the growth of corn plants and increase their resistance to adverse conditions $[12,11]$. In carrot plants, the application of iodine significantly improved nitrogen utilization from mineral fertilizers and thus could lower fertilizer doses applied to the soil. In storage of carrot roots cultivated without $\mathrm{N}$ nutrition, iodine treatment contributed to a significant increase in $\mathrm{P}, \mathrm{K}$, and $\mathrm{Ca}$ content and the 
Table 1. Height and physiological properties of corn (Zea mays L.) 'Cyrkon' grown under the predicted unfavorable temperature and soil moisture conditions and triple foliar sprayed with Cyanobacteria (mixture of Microcystis aeruginosa MKR 0105 and Anabaena sp. PCC 7120)

\begin{tabular}{|c|c|c|c|c|}
\hline \multirow{2}{*}{ Treatment of plants } & \multicolumn{3}{|c|}{ Temperature and soil moisture content during plant cultivation } & \multirow{2}{*}{$\mathrm{LSD}_{0.05}$} \\
\hline & $20^{\circ \circ} \mathrm{C}, 30 \%$ soil m.c. & $40^{\circ} \mathrm{C}, 30 \%$ soil m.c. & $20^{\circ} \mathrm{C}, 20-60 \%$ soil m.c. & \\
\hline \multicolumn{5}{|c|}{ Height of plants (cm) } \\
\hline Control & $88.2 \mathrm{~b}$ & $100.1 \mathrm{c}$ & $80.6 \mathrm{a}$ & \multirow[t]{2}{*}{7.85} \\
\hline Cyanobacteria & $100.5 \mathrm{c}$ & $120.7 \mathrm{~d}$ & $92.4 \mathrm{~b}$ & \\
\hline \multicolumn{5}{|c|}{ Electrolyte leakage after 2 hours $\left(\mu \mathrm{S} \mathrm{x} \mathrm{g}^{-1} \mathrm{x} \mathrm{ml}^{-1}\right)$} \\
\hline Control & $29.30 \mathrm{c}$ & $27.86 \mathrm{c}$ & $40.01 \mathrm{~d}$ & \multirow[t]{2}{*}{2.20} \\
\hline Cyanobacteria & $24.61 \mathrm{~b}$ & $21.80 \mathrm{a}$ & $20.80 \mathrm{a}$ & \\
\hline \multicolumn{5}{|c|}{ Electrolyte leakage after 4 hours $\left(\mu \mathrm{S} \times \mathrm{g}^{-1} \times \mathrm{ml}^{-1}\right)$} \\
\hline Control & $34.21 \mathrm{c}$ & $32.51 \mathrm{c}$ & $41.69 \mathrm{~d}$ & \multirow[t]{2}{*}{2.20} \\
\hline Cyanobacteria & $29.20 \mathrm{~b}$ & $24.20 \mathrm{a}$ & $23.20 \mathrm{a}$ & \\
\hline \multicolumn{5}{|c|}{ Activity of acid $(\mathrm{pH}=6)$ phosphatase ( $\mathrm{mU} \mathrm{g}^{-1}$ f.w. $)$} \\
\hline Control & $0.56 \mathrm{~b}$ & $0.90 \mathrm{~d}$ & $0.40 \mathrm{a}$ & \multirow[t]{2}{*}{0.15} \\
\hline Cyanobacteria & $0.86 \mathrm{~d}$ & $1.10 \mathrm{e}$ & $0.70 \mathrm{c}$ & \\
\hline \multicolumn{5}{|c|}{ Activity of alkaline $(\mathrm{pH}=7.5)$ phosphatase $\left(\mathrm{mU} \mathrm{g}^{-1}\right.$ f.w. $)$} \\
\hline Control & $0.20 \mathrm{~b}$ & $0.42 \mathrm{~d}$ & $0.10 \mathrm{a}$ & \multirow[t]{2}{*}{0.09} \\
\hline Cyanobacteria & $0.40 \mathrm{~d}$ & $0.61 \mathrm{e}$ & $0.30 \mathrm{c}$ & \\
\hline \multicolumn{5}{|c|}{ Activity of RNase ( $\mathrm{mU} \mathrm{g}^{-1}$ f.w.) } \\
\hline Control & $3.00 \mathrm{~b}$ & $4.87 \mathrm{~d}$ & $1.90 \mathrm{a}$ & \multirow[t]{2}{*}{0.58} \\
\hline Cyanobacteria & $4.00 \mathrm{c}$ & $5.48 \mathrm{e}$ & $3.70 \mathrm{c}$ & \\
\hline \multicolumn{5}{|c|}{ Index of chlorophyll content (SPAD units) } \\
\hline Control & $13.1 \mathrm{~b}$ & $35.1 \mathrm{~d}$ & $8.9 \mathrm{a}$ & \multirow[t]{2}{*}{3.3} \\
\hline Cyanobacteria & $37.8 \mathrm{de}$ & $39.9 \mathrm{e}$ & $27.7 \mathrm{c}$ & \\
\hline \multicolumn{5}{|c|}{ Net photosynthesis $\left(\mu \mathrm{m} \mathrm{CO}{ }_{2} \mathrm{~m}^{-2} \mathrm{~s}^{-1}\right)$} \\
\hline Control & $4.8 \mathrm{~b}$ & $5.7 \mathrm{~d}$ & $3.6 \mathrm{a}$ & \multirow[t]{2}{*}{0.2} \\
\hline Cyanobacteria & $5.0 \mathrm{c}$ & $6.3 \mathrm{e}$ & $4.8 \mathrm{~b}$ & \\
\hline \multicolumn{5}{|c|}{ Stomatal conductance $\left(\mathrm{mmol} \mathrm{H}_{2} \mathrm{O}^{-1} \mathrm{M}^{-2} \mathrm{~s}^{-1}\right)$} \\
\hline Control & $453 \mathrm{~b}$ & $538 \mathrm{c}$ & $375 \mathrm{a}$ & \multirow[t]{2}{*}{40.0} \\
\hline Cyanobacteria & $475 \mathrm{~b}$ & $582 \mathrm{~d}$ & $465 \mathrm{~b}$ & \\
\hline \multicolumn{5}{|c|}{ Transpiration $\left(\mathrm{mmol} \mathrm{H}_{2} \mathrm{O} \mathrm{m}^{-2} \mathrm{~s}^{-1}\right)$} \\
\hline Control & $1.32 \mathrm{~b}$ & $1.59 \mathrm{~d}$ & $1.03 \mathrm{a}$ & \multirow[t]{2}{*}{0.05} \\
\hline Cyanobacteria & $1.52 \mathrm{c}$ & $1.69 \mathrm{e}$ & $1.35 \mathrm{~b}$ & \\
\hline \multicolumn{5}{|c|}{ 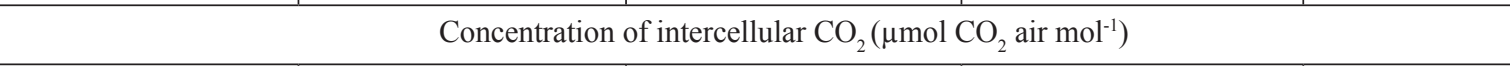 } \\
\hline Control & $298 \mathrm{c}$ & $281 \mathrm{~b}$ & $309 \mathrm{~d}$ & \multirow[t]{2}{*}{10.0} \\
\hline Cyanobacteria & $292 b c$ & $270 \mathrm{a}$ & $285 \mathrm{~b}$ & \\
\hline
\end{tabular}

reduction of Fe accumulation. It had no influence on $\mathrm{Mg}$, $\mathrm{S}, \mathrm{Cu}, \mathrm{Mn}, \mathrm{Zn}, \mathrm{Mo}, \mathrm{Al}$, and $\mathrm{Pb}$ contents in these roots. Increases in iodine concentration significantly enhanced iodine content in plants [17]. Ujowundu at al. also suggest possible changes in photosynthetic activity and uptake of important minerals after iodine application [14].

In lettuce, both in winter and summer trials, the application of iodate $\left(\mathrm{IO}_{3}^{-}\right)$or iodide $\left(\mathrm{I}^{-}\right)$did not affect plant 
biomass, although it increased quantity of these elements in leaves [15]. Research also suggests that biofortification of corn, as well as vegetables, with iodine (Biojodis) can become an alternative method to salt ionization and of introducing this element to the human diet [17]. The results obtained and the authors cited data show that iodine (in Biojodis) applied to the plants may improve their growth, uptake nutrients from the soil, and increase its contents in the tissues. Therefore, it can be recommended for organic crop production, purification of the environment from contaminants, and for introduction of iodine to human diet instead of salt iodization [17, 42].

Research showed also that the triple foliar application of non-toxic Cyanobacteria (mixture of Microcystis aeruginosa MKR 0105 and Anabaena sp. PCC 7120) not only stimulates corn development in favorable conditions but moreover can partly alleviate the harmful influence of adverse temperature, draught, and excessive watering stress on plant development. Treatments with non-toxic Cyanobacteria resulted in increased height and physiological activity in comparison to the control variant, in which the corn was sprayed with tap water only. These positive changes were in all variants, including different temperatures and soil moistures. These effects were observed using cell density, which was estimated to be $2.5 \times 105$ cells ml $^{-1}$ water. They could be modified by lower or higher density of the algae cells. The fact that foliar application of the studied strains increased corn growth could be caused by greater intensity of several physiological events and by plant enrichment with phytohormones, auxin (IAA), GA, cytokinins, amino acids, macronutrients $(\mathrm{N}, \mathrm{P}, \mathrm{K}, \mathrm{Ca}, \mathrm{Mg})$, microelements ( $\mathrm{S}, \mathrm{Zn}, \mathrm{Fe}, \mathrm{Mn}, \mathrm{Cu}, \mathrm{Mo}, \mathrm{Co}$ ), polyamines, and several other secondary metabolites that can be produced by Cyanobacteria and by nitrogen assimilated by these microorganisms from the atmosphere, as described in plants of several species grown in favorable conditions by Haroun and Hussein [18], Nain et al. [43], Masojídek and Práśil [19], Chojnacka et al. [20], Nunnery et al. [21], Perez-Garcia et al. [22], Pszczolkowski et al. [23], Rana et al. [44], Sahu et al. [33], Markou and Nerantzis [24], Grzesik and Romanowska-Duda [8], Michalak et al. [45], Corbel et al. [46 47], Mazur-Marzec [48], and El Khalloufi et al. [49].

Cyanobacteria are a bio-geo-chemically important component of diverse ecosystems that play a significant role in carbon and nitrogen cycling. They have the remarkable ability to form intimate symbiotic associations with a wide range of eukaryotic hosts belonging to different plant groups. The presented research shows that, due to a wide spectrum of positive influence on growth and physiological activity in plants, the evaluated non-toxic Cyanobacteria (mixture of monocultures of Microcystis aeruginosa MKR 0105 and Anabaena sp. PCC 7120) can be used in the future to stimulate corn development under adverse climate change conditions.

\section{Conclusions}

The expected changes of climate conditions may grossly determine development of corn (Zea mays L.) and adversely influence the food industry system and energy biomass production. The periodic prevalence of low temperatures or drought and excessive soil moisture can decrease corn development. Treatments of these plants with ecological Biojodis and non-toxic Cyanobacteria (a mixture of monocultures of Microcystis aeruginosa MKR 0105 and Anabaena sp. PCC 7120) increase the growth of plants under optimal and adverse temperature and soil moisture conditions, and partly restore the harmful effects of these stresses (climate-changed conditions) on plant development and physiological activity. Biojodis and non-toxic Cyanobacteria can be applied to ecological and integrated corn production in the predicted environmental constraints to improve the yield of plants and decrease environmental pollution.

\section{Acknowledgements}

Our research was sponsored by the Ministry of Science and Higher Education in Poland, Grant Nos. N N305 322035 and B1511000000999.02.

\section{References}

1. MILLS E. Insurance in a climate of change. Science 309, 1040, 2005

2. KUNDZEWICZ Z.W., TRYJANOWSKI P. Climatic extremes: Long-term changes and their impact. Kosmos, $\mathbf{5 7}$ (3-4), 251, 2008.

3. JANSEN L.H.J., VAN OEVAREN J.C., VAN ASSELT P.R., KUIPER P.J.C. Genotypic variation in chlorophyll fluorescence parameters, photosynthesis and growth of tomato grown at low temperature and low irradiance. Photosynthetica, 31, 301, 1995.

4. GORNIK K., GRZESIK M. Effect of Asahi SL on China aster 'Aleksandra' seed yield, germination and some metabolic events. Acta Physiologiae Plantarum. 24 (4), 379, 2002.

5. ROMANOWSKA-DUDA Z.B., KALAJI H., STRASSER R. The use of PSII activity of Spirodela oligorrhiza plants as an indicator for water toxicity. Fundamental Aspects to Global Perspectives. Photosynthesis Research. Special Issue: 585, 2005.

6. GRZESIK M., ROMANOWSKA-DUDA Z.B. The use of blue green algae in ecological plant production. Workshop of Inter. Research Network: Physiological and practical aspects of the yield and seed quality improvement by ecological methods; 21.06.2006, Warsaw: 16-17, 2006.

7. GRZESIK M., ROMANOWSKA-DUDA Z.B. The effect of potential climatic changes, Cyanobacteria, Biojodis and Asahi SL on development of the Virginia fanpetals (Sida hermaphrodita) plants. Pamiętnik Puławski: Zeszyt 151, 483, 2009.

8. GRZESIK M., ROMANOWSKA-DUDA Z.B. Ability of Cyanobacteria and microalgae in improvement of metabolic activity and development of willow plants. Polish Journal of Environmental Studies. DOI: 10.15244/pjoes/34667, 24 (3), 1003, 2015

9. GRZESIK M., ROMANOWSKA-DUDA Z.B., PIOTROWSKI K., JANAS R. Diatoms (Bacillariophyceae) as an effective base of a new generation of organic fertilizers. Okrzemki (Bacillariophyceae) jako efektywne bazy 
nawozów ekologicznych nowej generacji. Przemysł Chemiczny DOI: 10.15199/62.2015.3.27, 94 (3), 391, 2015.

10. ROMANOWSKA-DUDA Z.B, GÓRNIK K. Juvenile growth of cuttings under influence of biostimulators and algae. COST 858. Viticulture: Biotic and Abiotic StressGrapevine Defense Mechanisms and Grape Development. Prague, 14-16.09.2006, 39, 2006

11. JEZNACH A. Effect of iodine on the cabbage fruits ontogenesis and seed quality. M. Sc. thesis.(Pol).WSEH Skierniewice, Poland: 1-68, 2011.

12. SMOLEN S. Effect of nitrogen and iodine fertilization on the mineral content in carrot. Ochrona Środowiska i Zasobów Naturalnych 40, 270, 2009.

13. SZWONEK E. Impact of Foliar Fertilizer Containing Iodine on "Golden Delicious" Apple Trees. The Proceedings of the International Plant Nutrition Colloquium XVI, Department of Plant Sciences, UC Davis, UC Davis. 1-4, 2009.

14. UJOWUNDU C.O., UKOHA A.I, AGHA. C.N., NWACHUKWU N., IGWE K.O. Iodine Biofortification of selected plants using potassium iodide. Nigerian Journal of Biochemistry and Molecular Biology: 24 (2), 17, 2009.

15. VOOGT W., HOLWERDA H.T., KHODABAKS R. Biofortification of lettuce (Lactuca sativa $\mathrm{L}$.) with iodine: the effect of iodine form and concentration in the nutrient solution on growth, development and iodine uptake of lettuce grown in water culture. Journal of the Science of Food and Agriculture 5, 906, 2010.

16. STRZETELSKI P., SMOLEŃ S., ROŻEK S., SADY W. Effect of differentiated fertilization on the accumulation of iodine content of selected ingredients in plants radishes. Acta Scientiarum Polonorum - Hortorum Cultus: 9, 2010.

17. SMOLEŃ S., SADY W., ROŻEK S., LEDWOŻYWSMOLEŃ I., STRZETELSKI P. Preliminary evaluation of the influence of iodine and nitro gen fertilization on the effectiveness of iodine biofortification and mineral composition of carrot storage roots. Journal Elementology: 275, 2011.

18. HAROUN S.A., HUSSEIN M.H. The promotive effect of algal biofertilizers on growth, protein pattern and some metabolic activities of Lupinus termis plants grown in siliceous soil. Asian Journal of Plant Sciences. 2 (13), 944, 2003.

19. MASOJÍDEK J., PRÁŠIL O. The development of microalgal biotechnology in the Czech Republic. Journal of Industrial Microbiology and Biotechnology. 37 (12), 1307, 2010.

20. CHOJNACKA A., ROMANOWSKA-DUDA Z.B., GRZESIK M., PSZCZÓŁKOWSKI W., SAKOWICZ T. Cyanobacteria as a source of bioactive compounds for crop cultivation. In: K. Wolowski, J. Kwandrans, A.Z. Wojtal (Eds), Taxonomy the queen of science - the beauty of algae. Book of abstracts of the $29^{\text {th }}$ International Phycological Conference Krakow. 81, 2010.

21. NUNNERY J.K., MEVERS E., GERWICK W.H. Biologically active secondary metabolites from marine cyanobacteria. Current Opinion in Biotechnology. 21 (6), 787, 2010.

22. PEREZ-GARCIA O., ESCALANTE F.M.E., DE-BASHAN L.E., BASHAN Y. Heterotrophic cultures of microalgae: Metabolism and potential products. Water Research. 45, 11, 2011.

23. PSZCZÓŁKOWSKI W., ROMANOWSKA-DUDA Z.B., OWCZARCZYK A., GRZESIK M., SAKOWICZ T., CHOJNACKA A. Influence of secondary metabolites from Cyanobacteria on the growth and plant development. Phycological Reports: Current advances in algal taxonomy and its applications: phylogenetic, ecological and applied perspective. Institute of Botany Polish, Academy of Sciences, Kraków. 195, 2012.
24. MARKOU G., NERANTZIS E. Microalgae for high-value compounds and biofuels production: A review with focus on cultivation under stress conditions. Biotechnology Advances. 31, 1532, 2013.

25. SPILLER H., GUNASEKARAN M. Ammonia-excreting mutant strain of the cyanobacterium Anabaena variabilis supports growth of wheat. Applied of Microbiology and Biotechnology. 33 (4), 477, 1990.

26. NILSSON M., RASMUSSEN U., BERGMAN B. Competition among symbiotic cyanobacterial Nostoc strains forming artificial associations with rice (Oryza sativa). FEMS Microbiology Letters. 245, 139, 2005.

27. KARTHIKEYANB N., PRASANNAA R., NAINB L., KAUSHIK B.D. Evaluating the potential of plant growth promoting cyanobacteria as inoculants for wheat. European Journal of Soil Biology. 43 (1), 23, 2007.

28. THAJUDDIN N., SUBRAMANIAN G. Cyanobacterial biodiversity and potential applications in biotechnology. Current Science 89, 47, 2005.

29. SONG T., MARTENSSON L., ERIKSSON T., ZHENG W., RASMUSSEN U. Biodiversity and seasonal variation of the cyanobacterial assemblage in a rice paddy field in Fujian, China. The Federation of European Materials Societies Microbiology Ecology 54, 131, 2005.

30. ABD EL-MONIEM E., ABD-ALLAH ASE Effect of green alga cells extract as foliar spray on vegetative growth, yield and berries quality of superior grapevines. American-Eurasian J Agric \& Environ Sci 4 (4), 427, 2008.

31. SHANAN N.T., HIGAZY A.M. Integrated biofertilization management and cyanobacteria application to improve growth and flower quality of Matthiola incana. Research Journal of Agriculture and Biological Science. 5 (6), 1162, 2009.

32. ROMANOWSKA-DUDA Z.B., GRZESIK M., OWCZARCZYK A., MAZUR-MARZEC H. Impact of intra and extracellular substances from Cyanobacteria on the growth and physiological parameters of grapevine (Vitis vinifera). In: 20th International Conference on Plant Growth Substance (IPGSA), Book of abstracts 28.07-02.08.2010. Universitat Rovira i Virgili, Tarragona. Spain, 118, 2010.

33. SAHU D., PRIYADARSHANI I., RATH B. Cyanobacteriaas potential biofertilizer. CIB Tech Journal of Microbiology ISSN: 2319-3867. 1 (2-3), 20, 2012.

34. GRZESIK M., ROMANOWSKA-DUDA Z.B., PIOTROWSKI K. The effect of potential change in climatic conditions on the development of the energy willow (Salix viminalis) plants. Proceedings of the $2^{\text {nd }}$ International Conference on Environmental Management, Engineering, Planning and Economics (CEMEPE) and SECOTOX Conference, Mykonos, Ed: A. Kungolos, K. Aravossis, A. Karagiannidis, P. Samaras, GRAFIMA" Publ., D. Gounari 62-68, Thessaloniki, ISBN 978-960-6865-09-1, vol. IV: 1877-1882, 2009.

35. KALAJI M.H., CARPENTIER R., ALLAKHVERDIEV S.I., BOSA K. Fluorescence parameters as an early indicator of light stress in barley. J Photochem and Photobiol B 112, $1,2012$.

36. KALAJI M.H., SCHANSKER G., LADLE R.J., GOLTSEV V., BOSA K., ALLAKHVERDIEV S. I., BRESTIC M., BUSSOTTI F., CALATAYUD A., DĄBROWSKI P., ELSHEERY N. I., FERRONI L., GUIDI L., HOGEWONING S.W., JAJOO A., MISRA A.N., NEBAUER S.G., PANCALDI S., PENELLA C., POLI D., POLLASTRINI M., ROMANOWSKA-DUDA Z.B., RUTKOWSKA B., SERÔDIO J., SURESH K., SZULC W., TAMBUSSI E., YANNICCARI M., ZIVCAK M. Frequently Asked Questions about chlorophyll fluorescence: practical issues. Photosynthesis Research: 122, 121, 2014. 
37. KNYPL J.S., KABZIŃSKA E. Growth, phosphatase and ribonuclease activity in phosphate deficient Spirodela oligorrhiza cultures. Biochem. Physiol. Pflanzen. 17, 279, 1977.

38. PIOTROWSKI K., ROMANOWSKA-DUDA Z.B., GRZESIK M. Zmiany klimatyczne a uprawa roślin energetycznych. Acta Innovations nr 11, 20, 2014.

39. GÓRNIK K., GRZESIK M., MIKA A. Improvement of grapevines rooting and growth of plants under stress conditions by Asahi SL. Folia Horticulture. 19/2. 57, 2007.

40. BABIK J. Evaluation of the usefulness of Biojodis for use in the cultivation of vegetables. Raport of the Institute of Vegetable Crops. Skierniewice, Poland: 1-9, 2006.

41. BADEK B., ROMANOWSKA-DUDA Z.B., GRZESIK M., VAN DUIJN B. Rapid evaluation of primed China aster seed (Callistephus chinensis Ness.) germinability using physiological and biochemical markers. Journal of Horticultural Research 22 (2), 5, 2014.

42. CAFFAGNI A., ARRU L., MERIGGI P., MILC J., PERATA P., PECCIONI N. Iodine fortification plant screening process and accumulation in tomato fruits and potato tubers. Communications in Soil Science and Plant Analysis, 42, 706, 2011.

43. NAIN L., RANA A., JOSHI M., JADHAV S.D., KUMAR D., SHIVAY Y.S., PAUL S., PRASANNA R. Evaluation of synergistic effects of bacterial and cyanobacterial strains as biofertilizers for wheat. Plant Soil. 331, 217, 2010.

44. RANA A., JOSHI M., PRASANNA R., SHIVAY R.S., NAIN L. Biofortification of wheat through inoculation of plant growth promoting rhizobacteria and cyanobacteria. European Journal of Soil Biology. 50, 118, 2012.
45. MICHALAK I., DMYTRYK A., WIECZOREK P.P., RÓJ E., LESKA B., GÓRKA B., MESSYASZ B., LIPOK J., MIKULEWICZ M., WILK R., SCHROEDER G., CHOJNACKA K. Supercritical Algal Extracts: A Source of Biologically Active Compounds from Nature Journal of Chemistry. ID 597140. 1, 2015.

46. CORBEL S., BOUAICHA N., MARTIN-LAURENT F., CROUZET O., MOUGIN C. Soil irrigation with toxic cyanobacterial microcystins increases soil nitrification potential. Environ Chem Lett DOI 10.1007/s10311-015-0520-8. Springer International Publishing Switzerland. Published on line, 2015.

47. CORBEL S., MOUGIN C., MARTIN-LAURENT F., CROUZET O., BRU D., NELIEU S., BOUAICHA N. Evaluation of phytotoxicity and ecotoxicity potentials of a cyanobacterial extract containing microcystins under realistic environmental concentrations and in a soil-plant system. Chemosphere 128, 332, 2015.

48. MAZUR-MARZEC H., BŁASZCZYKA., FELCZYKOWSKA A., HOHLFELDA N., KOBOSA J., TORUŃSKASITARZ A., DEVIC P., MONTALVAOD S., D'SOUZAC L., TAMMELDA P., MIKOSIKE A., BLOCHB S., NEJMANFALEŃCZYK B., WEGRZYN G. Baltic cyanobacteria - a source of biologically active compounds European Journal of Phycology. DOI: 10.1080/09670262.2015.1062563. 50 (3), 343, 2015.

49. EL KHALLOUFI F., OUFDOU K., BERTRAND M., LAHROUNI M., OUDRA B., ORTET P., BARAKAT M., HEULIN T., ACHOUAK W. Microbiote shift in the Medicago sativa rhizosphere in response to cyanotoxins extract exposure. Science of the Total Environment 539. 135, 2016. 
